\title{
Ismat Chughtai's Depiction of Homophobia Through the Story 'Lihaaf'
}

Pranasha Shinde

Law Students

Mumbai University

Mumbai, Maharashtra, India

panasheshinde98@gmail.com

Dhananjay Shrikant Shinde

Law Students

O.P. Jindal Global University

Mumbai, Maharashtra, India

dshinde5223@gmail.com

Abstract

This study aims to bring attention to the homophobia of the famous female writer Ismat Chughtai with the help of her infamous short story 'Lihaaf' published in the pre-independent India. The short story 'Lihaaf' is a story of a homosexual woman named Begum Jan and her homosexual husband Nawab Saheb. Through this study, we are trying to bring the homophobic depiction of characters by the writer Ismat Chughtai in the short story 'Lihaaf', which has been ignored for a long time.

Keywords: Lihaaf, Ismat Chughtai, Homosexuality, Homophobia 


\section{Introduction}

Ismat Chughtai garnered extra attention in the world of writing and literature in colonial India by the publication of short story Lihaaf in the literary journal Adab-e-Lateef. The story was about Begum Jan, a newly married woman, who was ignored by her husband, who is interested in young boys. Because of her physical abandonment, she explores new methods of satisfying herself. The story is narrated by a child who used to stay with Begum Jan for a few days. For this short story, charges of obscenity were charged on Ismat Chughtai, which caused a lot of turmoil in her personal as well as professional life. Ismat Chughtai was known for her progressive, frank, bold, controversial, and witty style of writing, which set higher standards in writing for other writers. However, in my opinion, when we pay close attention to her short story Lihaaf, we can say that she was a homophobic person. This opinion is based on two things; firstly, in between the story, we can find that Ismat's opinions were hovering over the narrator's view and understanding towards homosexual people, and secondly, she portrayed the characters in a stereotypical and cliched manner although many people oppose this opinion.

\section{Lihaaf and Homophobia}

The story Lihaaf and the personal life of Ismat Chughtai are inextricably linked and are inseparable from each other" ${ }^{1}$. She even said that the story Lihaaf is a real story and not an imaginary story and it is based on the people she knew, and the incidents happened in her life, even her sister in law recognized the characters of the story when she read out the story to her before publishing the story in the journal. Ismat Chughtai and the adult narrator in the story have a similar outlook towards the homosexual people; we can notice the similarities between them throughout the story. In the story, the relationship of Begum Jan and Rabbu is

${ }^{1}$ From "The assertion of feminist sensibility in the short fiction of Ismat Chugtai". Chapter two, second paragraph, page number 1 
continuously viewed through the eyes of a now-adult narrator who disavows and disdains the relationship throughout the story whereas Ismat Chughtai once told that she considers the relationship of Begum Jan and Rabbu as a disease and she even wished that a man should come in Begum Jan's life and save her from the clutches of Rabbu. In the year 1942, in which the short story was published, it was common for people in Victorian England and its colonies to look down upon homosexuality and homosexual people and consider them as a disease or addiction, and Ismat was no different. The heteronormative ideas of colonial India influenced her; as a result, she had no sympathy or consideration towards homosexual people while writing the story, which resulted in disdaining and disavowing the relationship between Begum Jan and Rabbu. The close reading and the analysis of the story helps to prove the point that the narrator and Ismat Chughtai have a similar way of looking at homosexual people. There is a particular reason for using a child as the narrator of the story, which is being able to escape from the ignorant comments made while narrating the story. However, as the story progresses the details which the narrator notices and the ability to understand them such as Begum Jan's way of looking at the boys who came to meet Nawab Saheb, her being jealous of the boys for getting Nawab Saheb's attention, the constant itch which only Rabbu could satisfy, the cause of the itch, paying attention to the gossips regarding Begum Jan and Rabbu made by other servants, the closeness between Rabbu and Begum Jan, Begum Jan not allowing anyone else to touch her, Begum Jan's failed attempts to lure Nawab Saheb, are challenging to be noticed by a child. Therefore, we can say that there is a noticeable change in the narrative, as Ismat Chughtai puts her views forwards through the narrator.

The characters in the story, Lihaaf are typecast from a pedophile to opportunity taker, using their position of power to fulfill their sexual needs, and the most illogical one is that homosexuality is situational or temporary. Ruth Vanita and Saleem Kidwai rightly describe Lihaaf as an Indian fiction that depicts the love between women, but it is with a degree of 
homophobia. The character of Nawab Saheb and Begum Jan are both shown as exploitative people who take undue advantage of their higher position of power compared to the ones with whom they have a relationship. Nawab Saheb is shown interested in young, slender waisted, fair boys whose expenses were borne by him and in case of Begum Jan she is shown to have a relationship with her maidservant, in which she is in charge of paying her salary and is in the position to remove her from the job. The characters are also shown as pedophiles, Nawab Saheb is interested in young boys, and Begum Jan was shown to grab the narrator tightly and count her ribs, makes the narrator massage her. Ismat Chughtai ticks all the boxes of stereotypes and misconceptions regarding homosexual people. They are portrayed as bad people who take undue advantage of naïve people. In the beginning, Begum Jan was shown trying various methods to seduce Nawab Saheb. Then she was shown having an interest in the boys who visited Nawab Saheb regularly, as a result of multiple failed attempts of seducing Nawab Saheb. The problem is that Rabbu is shown as an alternative, replacement, final resort to fulfill her sexual desires and needs, which were not fulfilled by Nawab Saheb nor the boys who visited him. The transition of the sexual preference of Begum Jan is not natural; it is a result of not having a heterosexual relationship, unfulfilled sexual needs, multiple failed attempts of seducing Nawab Saheb, and no possibility of having a heterosexual relationship. The story is infamous for the celebration of same-sex love, i.e.,the relationship between Begum Jan and Rabbu. However, the question is, can we call the story about homosexual people who are gay and lesbian. The relationship in which a person wilfully and consciously chooses another person of the same sex as a romantic and erotic partner is termed as a homosexual relationship. However, the relationship between Rabbu and Begum Jan, Nawab Saheb and young boys are not in a homosexual relationship because of multiple complexities and contradictions in the positioning of the characters. 
Ismat Chughtai played a significant role in the development of Urdu literature by bringing forward the topics related to middle-class Muslim society, and she also holds an extraordinary place in Urdu literature as there was not any significant female writer who talked about these topics. "She depicted women in their traditional roles, through their depiction also emerge the broad contours of the New Woman on the literary terrain. This woman is resourceful, aware, confident, even aggressive. She is determined to overcome her deterministic constraints and seems to be acquiring a new identity" (Asauddin, 2009). Ismat mainly spoke about women's self-dependency, liberty and chose to talk about topics that other writers were afraid to do. Through her stories, Ismat wrote the characters in a way that women find them as a role model and made people aware of the effects and consequences of child marriage, remaining illiterate, dependency on men. She talked about the topics which were considered taboo and made them part of daily life conversations. She was among the very few writers who spoke about issues such as female sexuality, emotional, and psychology. Through her short story Lihaaf, she talked about female sexuality, emotional needs, and the most controversial topic lesbian relationship."This story is an expose, a tight slap to the oppressive politics of patriarchal set up which try to bind and restrain female sexuality by confining them within the zenana"2. In the story, the character of Begum Jan refuses to become a victim of patriarchal society and decides to live on her terms. Ismat did write the story about homosexuality, and it did become part of the daily life conversation of people. However, the way she brought the subject of homosexuality in front of people was wrong and problematic as it depicted homosexuality as a need based and situational. Ismat Chughtai also made a mistake stereotyping the characters and fell in the trap of heteronormative style of story writing. She portrayed homosexuality as a replacement or the

\footnotetext{
${ }^{2}$ From "CHUGHTAI'S THE QUILT: A MIRROR OF TROUBLED SEXUALITY" by R. Debnath. SAJMS, Volume 4(Issue
} 5), p. 266 
last resort of fulfilling sexual needs, and when there is no way of fulfilling sexual needs through a heterosexual relationship.

\section{Conclusion}

In conclusion, the short story Lihaaf by Ismat Chughtai is a revolutionary piece of literature as it deals with the topic of homosexuality but in a heteronormative way. She wrote this story in an attempt to make homosexuality a non-taboo subject in society. Lihaaf made people aware of homosexuality and became a part of people's daily life conversation. However, the way in which she dealt with the topic was wrong. Ismat Chughtai made the same mistake which other people did by stereotyping the characters and overshadowed her personal views and opinions on the narrator's views and opinion. 


\section{References}

Chaturvedi, S. (2018). Analysis of the idea of Heteronormative reality versus Personal identity as represented in Ismat Chughtai's"Lihaaf". SMART MOVES JOURNAL IJELLH, 6(12). Retrieved from DOI: https://doi.org/10.24113/ijellh.v6i12.6002

Sen, A. (2007) Feminist Ethnographies of Desire and Resistance in Lalithambika Antherjanam's "The Goddess of Revenge" and Ismat Chugtai's"Lihaaf", South Asian Review, 28:2, 165-181, DOI: 10.1080/02759527.2007.11932522Retrieved from https://www.tandfonline.com/doi/citedby/10.1080/02759527.2007.11932522?scroll=t op\&needAccess $=$ true

Sharma, A. (2017). Politics of the Queer in India: Space(s) and Text(s). (M.Phil dissertation, Sikkim University). Retrieved from http://dspace.cus.ac.in/jspui/handle/1/6010

Tellis, A. (2006). The Corporeal Aesthetic in Ismat Chughtai's Lihaaf. Lesbian Voices Canada and the World: Theory, Literature, Cinema. Retrieved from https://www.academia.edu/4066830/The_Corporeal_Aesthetic_in_Ismat_Chughtais_ Lihaaf

Wadood, B. (2016). The assertion of feminist sensibility in the short fiction of Ismat Chugtai. (Doctor of Philosophy, University of Lucknow). Retrieved from http://hdl.handle.net/10603/186367 